\title{
Pengaruh Corporate Governance Terhadap Nilai Perusahaan Manufaktur Yang Terdaftar Di BEI
}

\author{
Levina Nathania dan Indra Widjaja \\ Program Studi S1 Manajemen Fakultas Ekonomi Universitas Tarumanagara Jakarta \\ Email: levina.115150006@stu.untar.ac.id
}

\begin{abstract}
The purpose of this research are to find out the impact of corporate governance on firm value in manufacturing companies of consumption goods industrial sector listed in Indondesia Stock Exchange in 2014-2017. Researcher used purposive sampling to collect samples. There are 17 sample of manufacturing companies of consumption goods industrial sector on this research. Data source are collected from www.idx.co.id, and then using Panel Data regression analysis. The results concludes that managerial ownership have positive effect on firm value, institutional ownership have positive effect on firm value, independent commissary have negative effect on firm value, and audit committee have positive effect on firm value.
\end{abstract}

Keywords: Managerial Ownership, Institutional Ownership, Board Independence, Audit Committee, Firm Value (Tobin's Q)

\begin{abstract}
Abstrak: Tujuan dari penelitian ini adalah untuk mengetahui pengaruh corporate governance terhadap nilai perusahaan pada perusahaan manufaktur industri barang konsumsi yang terdaftar di Bursa Efek Indonesia periode 2014-2017. Peneliti menggunakan purposive sampling dalam mengumpulkan data. Sampel terdiri dari 17 perusahaan manufaktur sektor industri barang konsumsi. Sumber data diperoleh dari www.idx.co.id, dan analisis dilakukan dengan menggunakan Analisis Regresi Data Panel. Hasil menunjukkan bahwa kepemilikan manajerial memiliki pengaruh positif terhadap nilai perusahaan. Kepemilikan institusional memiliki pengaruh positif terhadap nilai perusahaan. Dewan komisaris independen memiliki pengaruh negatif terhadap nilai perusahaan. Komite audit memiliki pengaruh positif terhadap nilai perusahaan.
\end{abstract}

Kata kunci: Kepemilikan Manajerial, Kepemilikan Institusional, Dewan Komisaris Independen, Komite Audit, Nilai Perusahaan (Tobin's Q)

\section{LATAR BELAKANG}

Nilai perusahaan merupakan hal yang penting bagi perusahaan. Menurut (Brigham dan Daves, 2010) dalam (Saraswathi, Wiksuana, dan Rahyuda, 2016) memaksimalkan nilai perusahaan adalah tujuan setiap perusahaan, karena dengan memaksimalkan nilai perusahaan berarti memaksimalkan kemakmuran pemegang saham juga. Bagi manajemen perusahaan, kemakmuran pemegang saham merupakan hal penting yang harus dicapai. Kemakmuran bagi para pemilik dan pemegang saham merupakan tujuan setiap perusahaan yang dicapai dengan meningkatkan nilai perusahaan itu sendiri. Untuk mencapai tujuan perusahaan tersebut, pemilik cenderung menggunakan tenaga kerja profesional yaitu manajer. Akan tetapi, pihak manajer seringkali bertindak demi kepentingan sendiri dibandingkan kepentingan perusahaan, 
sehingga muncul konflik keagenan dimana terjadi konflik antara pemegang saham dan pihak manajer.

Teori keagenan menjelaskan masalah yang muncul antara pemegang saham dan pihak manajer, dimana pihak manajer yang diandalkan untuk menyediakan jasa atas nama pemegang saham bertindak sesuai kepentingan sendiri tanpa memperdulikan kepentingan pemegang saham. Oleh karena itu, diperlukan tata kelola perusahaan (corporate governance) yang baik untuk menghindari perbedaan kepentingan antara pemegang saham dan pihak manajer. Secara umum, corporate governance adalah suatu mekanisme antara pilihan serta tindakan manajer dengan kepentingan shareholders dimana keduanya saling menyeimbangi (Muryati dan Suardikha, 2014).

\section{KAJIAN TEORI}

Teori keagenan (Agency Theory) merupakan suatu hubungan yang terjadi antara pihak manajemen dengan pemegang saham. Dimana dalam teori ini, pihak manajemen adalah sebagai agen, dan pemegang saham adalah sebagai pemilik perusahaan atau principal. Dalam teori ini, pihak manajemen diberikan kewenangan untuk melaksanakan pekerjaan atas nama pemilik. Dalam perusahaan pada prakteknya, hal yang sering terjadi adalah munculnya suatu konflik yang disebut agency conflict dimana konflik ini terjadi antara pihak agen atau manajer (pihak yang diberikan kewenangan) dengan pihak pemilik atau pemegang saham (pihak yang memberikan kewenangan), dimana kedua belah pihak ini memiliki kepentingan yang berbeda. Perbedaan kepentingan ini terjadi ketika pihak agen dan pemilik lebih mementingkan kemakmuran pihaknya masing-masing, dan dengan adanya dorongan motivasi yang berbeda, maka dapat dilihat bahwa pihak manajemen tidak selalu mementingkan kepentingan pihak pemilik perusahaan. Apabila terjadi ketidaksetaraan tujuan, maka hal tersebut akan menghalangi tercapainya tujuan perusahaan dan menyebabkan kerugian perusahaan. (Jensen dan Meckling, 1976) dalam (Perdana dan Raharja, 2014).

Nilai perusahaan menggambarkan baik atau buruknya manajemen dalam mengelola kekayaan perusahaan, hal ini dapat dilihat dari ukuran kinerja keuangan. Perusahaan akan berusaha untuk memaksimalkan nilai perusahaannya (Budiyono dan Wulansari, 2018). Dan menurut (Rahayu, 2010) dalam (Putri dan Wirajaya, 2017), nilai perusahaan merupakan sebuah nilai yang mengukur taraf kualitas perusahaan dan sebuah nilai yang menerangkan seberapa bagus taraf kepentingan sebuah perusahaan di mata konsumennya. Berdasarkan beberapa definisi tersebut, maka dapat disimpulkan bahwa nilai perusahaan adalah suatu tolak ukur yang dimiliki perusahaan terkait kualitas dan tingkat keberhasilan perusahaan bagi para investor untuk menentukan keputusan investasi. Corporate governance merupakan seperangkat peraturan yang mengatur hubungan antara pemegang, pengurus atau pengelola perusahaan, pihak kreditor, pemerintah, karyawan, serta para pemangku kepentingan internal dan eksternal lainnya yang berkaitan dengan hak-hak dan kewajiban atau disebut sistem yang mengendalikan perusahaan Forum For Corporate Governance in Indonesia (FCGI) dalam (Mutmainah, 2015). Mekanisme dari corporate governance meliputi kepemilikan manajerial, kepemilikan institusional, komite audit (Muryati dan Suardikha, 2014), dewan komisaris independen (Khan, Tanveer dan Malik, 2017).

Menurut (Jensen dan Meckling, 1976) dalam (Putri dan Suprasto, 2016) kepemilikan manajerial merupakan kepemilikan saham perusahaan oleh manajer yang dinilai dapat menyelaraskan kedua perbedaan kepentingan antara manajer dan pemegang saham. Dengan meningkatnya jumlah saham yang dimiliki oleh manajer maka pengambilan keputusan akan dilakukan dengan lebih mempertimbangkan resiko yang ada (Muryati dan Suardikha, 2014). Hasil penelitian (Dwi Yana, 2007) dalam (Raharja dan Perdana, 2014), menunjukkan bahwa kepemilikan manajerial berpengaruh positif terhadap nilai perusahaan sementara menurut 
penelitian (Wida dan Suartana, 2014), kepemilikan manajerial tidak berpengaruh pada nilai perusahaan .

Kepemilikan institusional merupakan jumlah saham yang dimiliki oleh investor besar dari institusi luar seperti bank, perusahaan asuransi, dan perusahaan investasi. Dengan adanya kepemilikan institusional, investor dapat memonitor manajer perusahaan karena investor memiliki akses informasi terhadap perusahaan karena investasi (Muryati, dan Suardikha, 2014). Menurut penelitian (Wida dan Suartana, 2014), bahwa kepemilikan institusional memiliki pengaruh positif terhadap nilai perusahaan, dimana keterlibatan pihak institusional mampu membatasi perilaku manajer yang oportunistik. Hasil berbeda dengan penelitian (Juhandi et al., 2013), menunjukkan bahwa kepemilikan institusional memiliki pengaruh signifkan dan negatif terhadap nilai perusahaan yang menunjukkan bahwa semakin tinggi kepemilikan institusional maka nilai perusahaan akan semakin menurun.

Menurut (Bhagat dan Jefferis, 2002) dalam (Rouf, 2011), komite audit memiliki peran penting dalam corporate governance untuk meningkatkan nilai perusahaan dimana komite audit bertindak secara independen dan secara profesional untuk menghindari kecurangan finansial, komite audit bertanggung jawab dalam memberikan informasi finansial secara transparan untuk mengurangi ketidakcocokan informasi dan meningkatkan nilai perusahaan. Oleh karena itu, komite audit dapat menjadi mekanisme yang memonitor meningkatnya kualitas arus informasi antara pemegang saham dan manajer. Hal ini tidak sejalan dengan penelitian (Meindarto dan Lukiastuti, 2016), yang menunjukkan bahwa komite audit tidak berpengaruh signifikan terhadap nilai perusahaan karena peningkatan komite audit.

Dewan komisaris independen memiliki peran dengan mengkomunikasikan tujuan para pemegang saham kepada manajer dalam mengatasi teori keagenan. Dengan kehadiran komisaris independen dalam dewan dapat melakukan pengawasan yang tepat dan bertanggung jawab dalam menjamin shareholders (Khan, Tanveer, dan Malik, 2017). Menurut penelitian (Vintila dan Gherghina, 2013; Khan, Tanveer, dan Malik, 2017) menunjukkan bahwa ada pengaruh positif dan signifikan antara dewan komisaris independen dan nilai perusahaan. Kehadiran direksi non eksekutif dalam dewan memberikan reaksi positif kepada para investor dan pemegang saham, sehingga perusahaan yang diawasi dengan ketat akan meningkatkan keyakinan perusahaan sehingga meningkatkan nilai perusahaan. Hasil berbeda dengan penelitian (Prastuti dan Budiasih, 2015), yang menunjukkan bahwa dewan komisaris independen tidak memiliki pengaruh terhadap nilai perusahaan karena komposisi dewan komisaris independen kurang efisien dalam menjalankan fungsi pengawasan karena proporsi komisaris independen tidak mampu mendominasi setiap kebijakan yang diambil oleh dewan komisaris. 
Kerangka pemikiran dalam penelitian ini digambarkan sebagai berikut:

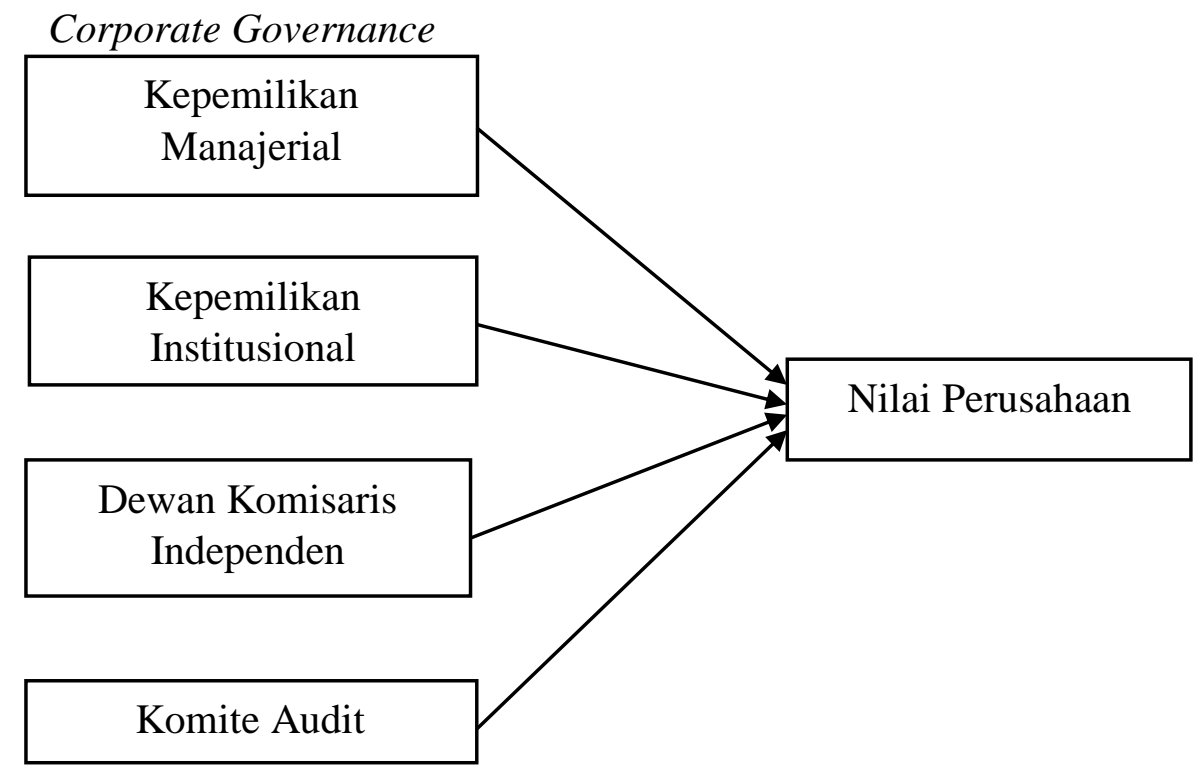

Gambar 1. Kerangka Pemikiran

Hipotesis dari model yang dibangun di atas adalah sebagai berikut:

$\mathrm{H}_{1}$ : Kepemilikan manajerial berpengaruh terhadap nilai perusahaan

$\mathrm{H}_{2}$ : Kepemilikan institusional berpengaruh terhadap nilai perusahaan

$\mathrm{H}_{3}$ : Dewan komisaris independen berpengaruh terhadap nilai perusahaan

$\mathrm{H}_{4}$ : Komite audit berpengaruh terhadap nilai perusahaan

\section{METODOLOGI}

Dalam penelitian ini, subjek yang digunakan adalah perusahaan manufaktur sektor industri barang konsumsi yang terdaftar di Bursa Efek Indonesia selama periode 2014-2017. Metode untuk pengambilan sampel yang digunakan dalam penelitian ini adalah purposive sampling dengan beberapa kriteria yang sebagai berikut: (1) Perusahaan manufaktur sektor industri barang konsumsi yang terdaftar di Bursa Efek Indonesia selama periode 2014-2017, (2) Perusahaan manufaktur sektor industri barang konsumsi yang terdaftar di Bursa Efek Indonesia sebelum tahun 2014, (3) Perusahaan manufaktur sektor industri barang konsumsi yang tidak mengalami delisting selama periode 2014-2017, (4) Perusahaan manufaktur sektor industri barang konsumsi yang melaporkan laporan keuangan dengan satuan mata uang rupiah, (5) Perusahaan manufaktur sektor industri barang konsumsi yang menerbitkan laporan keuangan tahunan yang menyediakan semua data yang dibutuhkan mengenai variabel penelitian yang terdiri dari kepemilikan manajerial, kepemilikan institusional, dewan komisaris independen, dan komite audit. Perusahaan yang diteliti adalah perusahaan manufaktur sektor industri barang konsumsi selama periode 2014-2017 yaitu 4 tahun, dari 43 perusahaan manufaktur sektor industri barang konsumsi, dan setelah dilakukan purposive sampling terdapat 17 perusahaan yang menjadi sampel penelitian.

Variabel operasional dalam penelitian ini yaitu kepemilikan manajerial, kepemilikan institusional, dewan komisaris independen, dan komite audit sebagai variabel independen dan nilai perusahaan sebagai variabel dependen. 
Dalam penelitian ini nilai perusahaan diwakili oleh Tobin's Q dengan rumus (Kurnia dan Wirasedana, 2018):

$$
\text { Tobin's Q }=\frac{\text { MVE }+ \text { DEBT }}{\text { TA }}
$$

Kepemilikan manajerial diwakili dengan MOWN dengan rumus (Kurnia dan Wirasedana, 2018):

$$
\text { MOWN }=\frac{\text { Jumlah saham yang dimiliki manajemen }}{\text { Jumlah saham yang beredar }}
$$

Kepemilikan institusional diwakili dengan INST dengan rumus (Kurnia dan Wirasedana, 2018):

$$
\text { INST }=\frac{\text { Jumlah saham yang dimiliki institusi }}{\text { Jumlah saham yang beredar }}
$$

Dewan komisaris independen diwakili dengan KI dengan rumus (Wardoyo dan Veronica, 2013):

$$
\mathrm{KI}=\frac{\text { Jml. Komisaris Independen }}{\text { Jml. Anggota Dewan Komisaris }}
$$

Komite audit diwakili dengan KA dengan rumus (Wardoyo dan Veronica, 2013):

$$
\mathrm{KA}=\Sigma \text { Komite Audit }
$$

Dalam penelitian ini menggunakan Uji Statistik Deskriptif, Uji Multikolinearitas, Uji Chow, Uji Hausman, Uji t dan Uji Koefisien Determinasi.

\section{HASIL UJI STATISTIK}

Uji statistik deskriptif memberikan gambaran tentang karakteristik variabel penelitian. Statistik deskriptif yang digunakan antara lain adalah rata-rata (mean), median, nilai maximum, nilai minimum dan standar deviasi. Hasil uji analisis deskriptif dari kepemilikan manajerial (MOWN), kepemilikan institusional (INST), dewan komisaris independen (KI), komite audit (KA) serta nilai perusahaan (Tobin'sQ) pada perusahaan manufaktur sektor industri barang konsumsi periode 2014-2017 menunjukkan bahwa nilai perusahaan (Tobin's Q) memiliki nilai rata-rata sebesar 1,660556 dengan median sebesar 1,157021 dan standar deviasi sebesar 1,291416, serta nilai mininum sebesar 0,431215 dan nilai maksimum sebesar 7,111081. Kepemilikan manajerial (MOWN) memiliki nilai rata-rata sebesar 0,063585 dengan median sebesar 0,007563 dan standar deviasi sebesar 0,121174, serta nilai mininum sebesar 0,000000 dan nilai maksimum sebesar 0,682755. Kepemilikan institusional (INST) memiliki nilai ratarata sebesar 0,448214 dengan median sebesar 0,455514 dan standar deviasi sebesar 0,301503, serta nilai mininum sebesar 0,009279 dan nilai maksimum sebesar 0,900252. Dewan komisaris independen (KI) memiliki nilai rata-rata sebesar 0,385084 dengan median sebesar 0,333333 dan standar deviasi sebesar 0,080173, serta nilai mininum sebesar 0,200000 dan nilai 
maksimum sebesar 0,500000. Komite audit (KA) memiliki nilai rata-rata sebesar 2,970588 dengan median sebesar 3,000000 dan standar deviasi sebesar 0,517473, serta nilai mininum sebesar 0,000000 dan nilai maksimum sebesar 4,000000.

Uji multikolinearitas. Untuk mengetahui keberadaan multikolinearitas dapat dilihat dari koefisien korelasi masing-masing variabel independen. Jika koefisien korelasi di antara masing-masing variabel independen lebih dari 0,8 , maka multikolinearitas terjadi. Dari hasil pengolahan data diperoleh bahwa korelasi antar variabel independen tidak ada yang lebih dari 0,8 sehingga dapat disimpulkan bahwa tidak terjadi multikolinearitas antar variabel independen perusahaan manufaktur sektor indsutri barang konsumsi yang digunakan.

Tabel 1. Uji Hausman

Correlated Random Effects - Hausman Test

Pool: Untitled

Test cross-section random effects

\begin{tabular}{llcc}
\hline \hline Test Summary & \multicolumn{1}{c}{ Chi-Sq. } \\
Statistic Chi-Sq. d.f. & Prob. \\
\hline \hline Cross-section random & 18.356744 & 4 & 0.0011 \\
\hline \hline
\end{tabular}

Uji chow untuk menentukan model Pooled Least Square atau Fixed Effect yang akan digunakan. Hasil Uji Chow yang diperoleh bahwa nilai cross-section F dan cross-section Chisquare sebesar 0.0000 , lebih kecil dari taraf signifikansi yaitu 0,05 yang berarti $\mathrm{H}_{0}$ ditolak sehingga model yang dipilih adalah Fixed Effect. Selanjutnya, Uji Hausman akan kembali diteliti untuk melihat apakah penelitian ini menggunakan Fixed Effect atau Random Effect. Hasil uji Hausman menunjukkan bahwa hasil nilai probabilitas uji Hausman yaitu sebesar 0.0011 , lebih kecil dari taraf signifikansi $(\alpha)$ yaitu 0,05 yang berarti $\mathrm{H}_{0}$ ditolak dan $\mathrm{H}_{\mathrm{a}}$ diterima, sehingga disimpulkan model yang digunakan adalah Fixed Effect.

Hasil analisis regresi berganda dapat disimpulkan dengan persamaan sebagai berikut:

$$
\begin{gathered}
\text { Tobin's } Q=0,299320+4,805753 * \text { MOWN }+5,082017 * I N S T-4,252362 * K I+ \\
0,139820 * K A
\end{gathered}
$$

Dari persamaan regresi diatas memiliki pengertian bahwa jika konstanta sebesar 0,299320, artinya jika kepemilikan manajerial (MOWN), kepemilikan institusional (INST), dewan komisaris independen (KI), dan komite audit (KA) nilainya dianggap 0 , maka nilai perusahaan bernilai 0,299320. Jika terjadi kenaikan satu satuan pada kepemilikan manajerial (MOWN) dan variabel independen lain dianggap konstan maka nilai perusahaan (Tobin's Q) akan naik sebesar 4,805753 satuan. Jika terjadi kenaikan satu satuan pada kepemilikan institusional (INST) dan variabel independen lain dianggap konstan maka nilai perusahaan (Tobin's Q) akan naik sebesar 5,082017 satuan. Jika terjadi kenaikan satu satuan pada komisaris independen (KI) dan variabel independen lain dianggap konstan maka nilai perusahaan (Tobin's Q) akan turun sebesar 4,252362 satuan. 
Jika terjadi kenaikan satu satuan pada komite audit (KA) dan variabel independen lain dianggap konstan maka maka nilai perusahaan (Tobin's Q) akan naik sebesar 0,139820 satuan.

Tabel 2. Uji-t

\begin{tabular}{|c|c|c|c|c|}
\hline \multicolumn{5}{|c|}{$\begin{array}{l}\text { Dependent Variable: TOBIN_S_Q } \\
\text { Method: Panel Least Squares } \\
\text { Date: } 11 / 21 / 18 \text { Time: } 21: 38 \\
\text { Sample: } 20142017 \\
\text { Periods included: } 4 \\
\text { Cross-sections included: } 17 \\
\text { Total panel (balanced) observations: } 68\end{array}$} \\
\hline Variable & Coefficient & Std. Error & t-Statistic & Prob. \\
\hline $\mathrm{C}$ & 0.299320 & 0.744043 & 0.402288 & 0.6893 \\
\hline MOWN & 4.805753 & 0.774696 & 6.203405 & 0.0000 \\
\hline INST & 5.082017 & 0.881917 & 5.762468 & 0.0000 \\
\hline $\mathrm{KI}$ & -4.252362 & 1.352129 & -3.144938 & 0.0029 \\
\hline KA & 0.139820 & 0.139155 & 1.004778 & 0.3201 \\
\hline \multicolumn{5}{|c|}{ Effects Specification } \\
\hline \multicolumn{5}{|c|}{ Cross-section fixed (dummy variables) } \\
\hline R-squared & 0.924618 & \multicolumn{2}{|c|}{ Mean dependent var } & 1.660556 \\
\hline Adjusted R-squared & 0.892540 & \multicolumn{2}{|c|}{ S.D. dependent var } & 1.291416 \\
\hline S.E. of regression & 0.423340 & \multicolumn{2}{|c|}{ Akaike info criterion } & 1.367006 \\
\hline Sum squared resid & 8.423201 & \multicolumn{2}{|c|}{ Schwarz criterion } & 2.052443 \\
\hline Log likelihood & -25.47822 & & 1.638597 \\
\hline F-statistic & 28.82436 & & & 2.179721 \\
\hline Prob(F-statistic) & 0.000000 & \multicolumn{2}{|c|}{ Durbin-Watson stat } & \\
\hline
\end{tabular}

Uji-t dilakukan untuk menunjukkan pengaruh dari masing-masing variabel independen secara individual terhadap variabel dependen. Untuk menguji $\mathrm{H}_{0}$ ditolak atau diterima, dapat dilihat dari hasil nilai probabilitas dibandingkan dengan tingkat keyakinan sebesar 5\%. Jika nilai probabilitas lebih kecil dari tingkat keyakinan maka $\mathrm{H}_{0}$ ditolak dan $\mathrm{H}_{a}$ diterima dan sebaliknya. Uji koefisien determinasi Uji koefisien determinasi dilakukan untuk menjelaskan perubahan dari variasi variabel terikat yang dapat dijelaskan oleh variasi variabel bebas. Dari tabel di atas menunjukkan bahwa bahwa nilai Adjusted $R$-squared dari nilai perusahaan (Tobin's Q) yaitu sebesar 0,892540 yang artinya sebesar 89,25\% variabel Tobin's Q dapat dijelaskan oleh MOWN, INST, KI dan KA dan 10,75\% dijelaskan oleh variabel lain di luar dari variabel bebas dalam penelitian ini.

\section{DISKUSI}

Hasil pengujian statistik menunjukkan bahwa Kepemilikan Manajerial (MOWN) memiliki pengaruh positif dan signifikan terhadap Nilai Perusahaan (Tobin's Q). Hasil pengujian statistik menunjukkan bahwa Kepemilikan Institusional (INST) memiliki pengaruh positif dan signifikan terhadap Nilai Perusahaan (Tobin's Q). Hasil pengujian statistik menunjukkan 
bahwa Dewan Komisaris Independen (KI) memiliki pengaruh negatif dan signifikan terhadap Nilai Perusahaan (Tobin's Q) perusahaan manufaktur sektor industri barang konsumsi periode 2014-2017. Hasil pengujian statistik menunjukkan bahwa Komite Audit (KA) tidak memiliki pengaruh yang signifikan terhadap Nilai Perusahaan (Tobin's Q).

\section{PENUTUP}

Berdasarkan hasil pengujian data yang dilakukan dalam penelitian ini dengan menggunakan EViews 9 pada perusahaan manufaktur sektor industri barang konsumsi pada periode 20142017, kepemilikan manajerial, kepemilikan institusional, dan dewan komisaris independen memiliki pengaruh terhadap nilai perusahaan.

Keterbatasan dari penelitian ini dikarenakan penelitian ini hanya menggunakan periode penelitian sebanyak 4 tahun dan penelitian ini hanya menggunakan 4 mekanisme corporate governance.

Berdasarkan hasil dan keterbatasan di atas, maka berikut saran yang dapat diberikan untuk penelitian selanjutnya yaitu untuk penelitian selanjutnya diharapkan agar menambahkan beberapa mekanisme corporate governance lainnya dan untuk penelitian selanjutnya diharapkan agar menambah periode prediksi dan jumlah observasi.

\section{DAFTAR PUSTAKA}

Budiyono, and Wulansari, F. A. (2018). GOOD CORPORATE GOVERNANCE MANAGEMENT ON CORPORATE VALUES (Empirical Study on Chemical Companies listed on the Indonesia Stock Exchange Period 2013-2015). International Journal of Economics, Business and Accounting Research, 2(1), 46-56.

Juhandi, N., Sudarma, M., Aisjah, S., and Rofiaty. (2013). The Effects of Internal factors and Stock Ownership Structure on Dividend Policy on Company's Value [A Study on Manufacturing Companies Listed on the Indonesia Stock Exchange (IDX)]. International Journal of Business and Management Invention, 2(11), 6-18.

Khan, A., Tanveer, S., and Malik, U. (2017). An empirical analysis of corporate governance and firm value: Evidence from KSE-100 Index. Accounting, 3, 119-130.

Kurnia, A.D., dan Wirasedana, P., (2018). Pengaruh Kinerja Lingkungan dan Komponen Good Corporate Governance pada Nilai Perusahaan yang Terdaftar di BEI. E-Jurnal Akuntansi Universitas Udayana, 24, 1737-1767.

Meindarto, A., dan Lukiastuti, F., (2016). Pengaruh Corporate Governance terhadap Nilai Perusahaan Pada Perusahaan Perbankan yang Terdaftar di BEI Tahun 2011-2014. Telaah Bisnis, 17(2), 145-168.

Muryati, N. N. T. S., dan Suardhika, I. M. S., (2014). Pengaruh Corporate Governance pada Nilai Perusahaan. E-Jurnal Akuntansi Universitas Udayana, 9(2), 411-429.

Mutmainah. (2015). Analisis Good Corporate Governance Terhadap Nilai Perusahaan. EJournal Stiedewantara, 10(2), 182-195.

Raharja, dan Perdana, R. S. (2014). Analisis Pengaruh Corporate Governance Terhadap Nilai Perusahaan. Diponegoro Journal of Accounting, 3(3), 1-13.

Prastuti, N. K. K., dan Budiasih, I. G. A. N. (2015). Pengaruh Good Corporate Governance pada Nilai Perusahaan dengan Moderasi Corporate Social Responsibility. E-Jurnal Akuntansi Universitas Udayana, 13(1), 114-129.

Pratiwi, R. D., dan Ghozali, I. (2012). Pengaruh Mekanisme Corporate Governance Terhadap Nilai Perusahaan. Media Ekonomi \& Teknologi Informasi, 20(2), 1-15.

Putri, I. A. S., dan Suprasto, B. H. (2016). PENGARUH TANGGUNG JAWAB SOSIAL 
PERUSAHAAN DAN MEKANISME TATA KELOLA PERUSAHAAN TERHADAP NILAI PERUSAHAAN. E-Jurnal Akuntansi Universitas Udayana, 15(1), 667-694.

Putri, K. I. H. K., dan Wirajaya, I. G. A. (2017). PENGARUH KINERJA KEUANGAN PADA

NILAI PERUSAHAAN DENGAN GOOD CORPORATE GOVERNANCE SEBAGAI

VARIABEL PEMODERASI. E-Jurnal Akuntansi Universitas Udayana, 21(1), 1-28.

Rouf, A. (2011). The Relationship between Corporate Governance and Value of the Firm in

Developing Countries: Evidence from Bangladesh. The International Journal of Applied Economics and Finance, 5(3), 237-244.

Saraswathi, I. A. A., Wiksuana, I. G. B., dan Rahyuda, H. (2016). PENGARUH RISIKO BISNIS, PERTUMBUHAN PERUSAHAAN DAN STRUKTUR MODAL TERHADAP PROFITABILITAS SERTA NILAI PERUSAHAAN MANUFAKTUR. E-Jurnal Ekonomi dan Bisnis Universitas Udayana, 5(6), 1729-1756.

Wardoyo, dan Veronica, T. M. (2013). PENGARUH GOOD CORPORATE GOVERNANCE, CORPORATE SOCIAL RESPONSIBILITY \& KINERJA KEUANGAN TERHADAP NILAI PERUSAHAAN. Jurnal Dinamika Manajemen, 4(2), 132-149.

Wida, N. P. P. D., dan Suartana, I. W. (2014). PENGARUH KEPEMILIKAN MANAJERIAL DAN KEPEMILIKAN INSTITUSIONAL PADA NILAI PERUSAHAAN. E-Jurnal Akuntansi Universitas Udayana, 9(3), 575-590. 